\title{
In Pursuit of Promoting Moderate Indonesian Islam to the world: Understanding the diversity of Islamic practices in Bima, Sumbawa Island
}

\author{
Muhammad Adlin Sila,Ph.D \\ FISIP UIN JAKARTA \\ silaadlin2000@gmail.com
}

\begin{abstract}
This paper suggests an ethnographic account of the different Islamic practices among Muslims in Bima, Sumbawa island. This paper calls for the need to understand that Islam in Indonesia is diverse. Anthropological works on Javanese Islam have shaped the national and international understandings of Islam in Indonesia [1][2][3]. Assessments of political, organizational forms and institutional elites have also focused on the Javanese centre of the nation-state. The account of Islamic picture outside Java Island is, however, understudied. This paper argues that Islamic practices vary significantly across Indonesia Islam, not only within Java itself, but outside Java. Cultural diversity and ecological adaptation have made Islam in Indonesia is complex. Through a 12-mont-fieldwork in Bima (2011-2012), I found that although Islam becomes the unifying factor, varied expressions of Islamic practices among Muslims reflect different cultural legacies and socio-political contexts. Although differences arise, Bima Muslims are able to mediate the differences and to foster harmony among them.
\end{abstract}

Keywords - Islam, Eastern Indonesia, Islamic diversity, Bima, Sumbawa.

\section{INTRODUCTION}

This paper argues that Islam in Bima is exceptionally a majority religion and it is misleading to conceive that Islam in the region is marginal and superficial in manner. This paper depicts that Islam in eastern Indonesia is complex and multivocal. If many anthropologists come to the term of syncretism to judge such practices, this paper analyzes the society under study beyond the perspective in characterizing Islam in Bima. The coming of Islam to Bima was related to its trading connection with Malay Sultanates like with the most prominent Gowa Sultanate of Makassar. As Islam first came to the kings, the picture of Islam in Bima was slightly the same with Makassar. That is, Islam spread out within the kingdom milieu and shaped the political system of Bima kingdom. This conversion to the new religion has manifold impact: it affects politics, religious practices and culture of the people of Bima. The kingdom of Bima changed to become the Sultanate of Bima whereby the term raja turned to be called a sultan. Although its religious practices are presumably syncretic, Bima Muslims are among the practicing Muslims (Muslim taat) in Indonesia.
This paper enquires the emergence of Islamic reformists in the region which influence the relation between adat (local tradition) and Islam. In doing this, this paper calls for not jumping to the conclusion in addressing traditions of Bima Muslims as syncretic, but introduces a new perspective on understanding the present Islamic outlook of Bima as the result of past and present adaptations. It addresses the local practice of Islamic prayers and festivals viewed as normative to Islam. The conversion of Bima to Islam has been accomplished by accommodation and integration within vibrant local cultural traditions. Studying Islam in Bima is therefore still of importance as it has become a much neglected topic and received little scholarly attention in the English literature.

\section{THE PICTURE OF ISLAM IN BIMA}

In eastern Indonesia, Bima became both a key site of Islamisation. Since Islam first introduced to the kings by Malay preachers from Minangkabau in the early $17^{\text {th }}$ century, the picture of ideal and truly Islam is presumably belong to the kingdom practices. The religious landscape of the village areas in Bima, however, is found as an amalgam of Islamic and pre-Islamic beliefs and ritual practices that anthropologists usually subsume under the notion of syncretism. The present day Bima is experiencing Islamic dakwah (preaching) which puts forward the idea of going back to the original sources of Islam. A scholar like Michael Prager has noticed this purifying movement [4]. Despite his brief historical outline of the Islamisation of Bima, he identifies the factors contributing to the local upsurge of reformist Islam embodied by the local Mecca pilgrims (Haji) and discusses the fundamental religious changes brought for example by Muhammadiyah - a reformist Muslim organization.

In today Bima, the people consider Islam as their religion and are keen to show their Islamic identity to be more evident. Many Bima people had saved enough money to make the $H a j j$, or the pilgrimage to Mecca, and upon their return, they should be wearing the white peci (Islamic hat) and were quite proud of that. According to the local staff of Kementerian 
Agama (Religious Ministry) of Bima, on 9 Oktober 2010, that the total number of 396 Hajj candidates (I. calon Jemaah Haji or calhaj) in Bima kabupaten would be sent to Mecca on 4 and 6 November 2010. This number had successfully reached the target that already carried out by the local authority of Kementerian Agama in Bima this year. This calhaj was placed in a group of flight (kelompok terbang or kloter) that is kloter 74 along with 163 calhaj from Mataram and 116 calhaj from Sumbawa [5].

The Qur'an reading is being held at the mosque every prayer times nearby mosques, broadcasted by loudspeakers. If you are foreigner and staying next to a mosque, you will be first annoyed but later on get used to the call to prayer (azan) early in the morning and even start to miss it after a while when you leave. Muslims of Bima are now among the fanatics in Indonesia. The Koran reading regional championship was being held at the park that night. They had a wide screen set up so everyone could view the contestants. Loudspeakers were strategically placed around the square. Bima regularly become a place for regional competition for reading the Qur'an. The first place contestants got to go to the nationals and if they were good enough to the international competition. Despite their adoption of the world religion and many associated cultural elements, the local people are both strongly Muslim and patriotic to their local identity [6]. Hitchcock's study concludes that despite Islamic identity being strong among Bima Muslims, they did not totally abandon non-Islamic elements [7]. He suggests, however, that the Islamic outlook of Bima Muslims is 'superficial'. In my view, as I found, Hitchcock fails to grasp the complexity of the religious observance of Bima Muslims and the nature of their religious subjectivity.

\section{MOVING BEYOND SYNCRETISM PARADIGM}

This study continues on to do what has been provoked deliberately by Danilyn Rutherford in a review article entitled "After Syncretism: The Anthropology of Islam and Christianity in Southeast Asia". The article managed to review three works respectively; Fields of the Lord: Animism, Christian Minorities, and State Development in Indonesia by Lorraine Aragon; Muslims through Discourse: Religion and Ritual in Gayo Society by John Bowen; and Power and Intimacy in the Christian Philippines by Fenella Cannell. This review is published in Comparative Studies in Society and History, published by Cambridge University Press. In this review, considered that the study on Islam for example, has seen Islam as historically emergent fields of practice and debate [8]. But this study also fulfilled the contingencies of Colonial scholarship. That is when it came to Islam, the "notion that the Javanese were syncretistic - i.e. not really Muslims at all - proved reassuring to colonial administrators who associated rebellion with the influence of the "fanatics"men whose faith was presumably pure." Syncretism has formed a dominant theme in studies of diversity among Indonesian Muslims; typically conceptualized as the accretion of bits and pieces remaining from past eras and local culture [9].

In the exploration of Islam in Bima, I follow Asad through his 'discursive tradition' to represent a new generation of studies of Indonesian Islam that moves beyond the blunt instrument of 'syncretism', a concept that fails to capture the dynamic character of cultural processes [10]. Even in Java, however, ethnographic studies show extraordinary variety of religious expression [11]. In his study on Islam in the Sultanate of Yogyakarta Keraton, in the reverse said that Islam is the core in the Javanese culture and not Hindusim [3]. Likewise, Andrew Beatty in his book, Varieties of Javanese Religion, offers a bottom-up view of Javanese religion, based on fieldwork carried out in an Osing village near Banyuwangi, in East Java [9]. Beatty's study has inevitably been compared to Clifford Geertz's The Religion of Java, but it is in many ways more compelling. It is strongly grounded in details of everyday religious practice and it captures the depth of diversity within a single community. Beatty begins with the slametan, ceremonial feasts in which almost everyone takes part, with guests invited on the basis of neighbourhood or kinship rather than religion. Participants, however, place radically different interpretations on the events of the slametan, making it multivocal. A key chapter surveys the diversity of mainstream Islam. Moulded by practical and local concerns, many different approaches to Islam coexist, with a balance between santri and non-santri and between ritual and dogma. The term is frequently employed pejoratively among Muslims themselves, undermining or qualifying their individual and collective expressions of Islamic identity.

This study of Islam in Bima added the existing studies of Islam in eastern Indonesia which anthropology has been always put emphasis on the studies of customary forms of social organization. Another thing is that this study responds to the call by several authors that scholars move beyond Java in characterizing Islam in Indonesia. The picture in eastern Indonesia is even more complex, and the few studies that have explored the politics of Islamic sultanates, conversion and contemporary expressions of Islam in this region, are patchy and insufficient to counter the assumptions about Indonesian Islam that derive from Java.

This study looked at the perspectives of the local people on normative religious practices, and the tendency of presenting Islam in more formal way such as Islamic by-laws vis-a-vis national law. In the former sultanate of Bima, kinship ties are still of great relevance even in a world of 'Islamic modernism' in which returning pilgrims receive important positions in village society and play a significant role in reorganizing and 
reshaping village social life. Descriptions of the full range of distinctive variants of Muslim life worlds, represented by their adherents as being Islam, are critical to the comparative ethnography of Islam [12]. I approach the question of what constitutes being Muslim in eastern Indonesia as a matter of social practice rather than theology or jural orthodoxy, grounding our understanding in social arrangements and selfidentity [13], the production, maintenance and transformation of specific traditions of Muslim life, and 'the efforts of practitioners to achieve coherence' [10]. Through this approach, I explore the social conditions influencing the existence of particular religious practices and discourses among Muslims, while recognizing the 'historically constituted complexity of tradition' [11]. In addition to that, this study addresses a major gap in disciplinary knowledge: the local practice of ritual activities viewed as normative to Islam. Anthropologists working in Muslim areas have tended to focus on 'folk beliefs' and examples of 'unorthodoxy' rather than on forms of Islamic prayer.

Another important aspect is to identify the very beginning, or what Lewis called origins, of the Bima people underpinning the social hierarchy as it is today. And the notions of origin may vary from one society to another but are generally cited in terms of "common metaphors based on recognizable cognate expressions". This is what Fox said is a distinctive Austronesian characteristic [14]. As regards origins in Bima, the easiest access to these is the witness of the elders or what the Bima called $B o$ (stories of the elders). This tells the concept of origins or notions of ancestry and social rank in Bima society. In doing that, this study combined threefold sources; ethnography, local narratives (life stories) and manuscripts, in the understanding of present development of Islam in Bima.

\section{IV.CONCLUDING REMARKS}

The study discusses comprehensively the ways local Muslim actors perform Islamic identities, which can encompass ideas of religious purity and hybridity; whether accommodations or amalgamations have occurred in religious practices (and whether this is good or bad); arguments for or against religious mixing; and competition over definitions of syncretism. The study takes established anthropological insights concerning the multivocality of ritual and symbolic practice - and the resulting scope for both social tension and cohesion - in a new direction, by combining it with an exploration of the social and political constraints to religious innovation and interpretation among a diversity of Muslim communities linked by parallel historical influences and contemporary political challenges. Following Asad's notion of 'discursive tradition', I found that Islamic practices as observed in rituals and festivals in Bima must be understood within the framework of how foundational texts are interpreted and contested among Muslims in the making of the Islamic practices [10]. Asad requires us to pay attention to the discourse rather than the text.

In short, this study tries instead to recognize that religious practices are always the result of synthesis, interaction and change, both past and present. And as such, to borrow Brakel, 'it would be a considerable error to speak of a uniform Indonesian Islam' [15]. In other words, this study responds to the call by several authors that scholars move beyond Java in characterizing Islam in Indonesia because the Islamic outlook in eastern Indonesia is even more complex, such concepts as the politics of Islamic sultanates, conversion and contemporary expressions of Islam in this region are insufficient to counter the assumptions about Indonesian Islam that derives from Java. 


\section{References}

[1] Geertz, Clifford. 1960 The Religion of Java. University of Chicago Press.

[2] Hefner, Robert W. 1985. Hindu Javanese. Tengger Tradition \& Islam. Princeton University Press, Princeton NJ.

[3] Woodward, Mark 1989, Islam in Java: Normative Piety and Mysticism in the Sultanate of Yogyakarta, Tucson: the University of Arizona Press.

[4] Prager, Michael. 2010. ABANDONING THE 'GARDEN OF MAGIC' : Islamic modernism and contested spirit assertions in Bima. Indonesia and the Malay World, Volume 38, Issue 110 March 2010 , pages 9 - 25.

[5] http://www.bimakab.go.id, accessed on 10 November 2010.

[6] Hitchcock, Michael. 1996 Islam and Identity in Eastern Indonesia University of Hull Press.

[7] Ibid., pp. 1-20.

[8] (http://www.jstor.org/stable/3879406) , accessed on 20 November 2010.

[9] Beatty, Andrew 1999 Varieties of Javanese Religion. An Anthropological Account. Cambridge University Press.

[10] Asad, Talal 1986 The Idea of an Anthropology of Islam Occasional Papers Series. Center for Contemporary Arab Studies, Georgetown University, Washington, D.C .

[11] Fox, James, J. 2002. "Toward a Social Anthropology of Islam in Indonesia”. In Fu'ad Jabali \& Jamhari (eds.) Islam in Indonesia. Islamic Studies and Social Transformation. Indonesia-Canada Islamic Higher Education Project Montreal \& Jakarta. pp 73-81.

Lukens-Bull, Ronald A. 1999 Between text and practice: considerations in the anthropological study of Islam. Marburg Journal of Religion 4 (2): 1-10.

[13] Ellen, Roy 1983 'Social Theory, ethnography and the understanding of practical Islam in South-east Asia'. In M. B.

[14] Fox, James J and Sather, Clifford (1996), Origins, Ancestry and Alliance: explorations in Austronesian Ethnography. Canberra, A.C.T: Department of Anthropology, Research School of Pacific and Asian Studies, the Australian National University.

[15] L.F. Brakel. "Islam and local traditions: syncretic ideas and practices". Indonesia and the Malay World, 1469-8382, Volume 32, Issue 92, 2004, Pages 5 - 20. 